\title{
Development of the Lower Central Plain of Thailand with History of Human Settlements: Evidence from Pollen, Spores and Diatoms
}

\author{
Wickanet Songtham ${ }^{1}$, Sumalee Musika ${ }^{1}$, Dallas C. Mildenhall ${ }^{2}$, Ursula A. Cochran ${ }^{2}$ and Darya Kojevnikova ${ }^{3}$ \\ 1. Northeastern Research Institute of Petrified Wood and Mineral Resources, Nakhon Ratchasima Rajabhat University, Nakhon \\ Ratchasima 30000, Thailand \\ 2. GNS Science, Lower Hutt, PO Box 30 368, New Zealand \\ 3. Institute of Geology, Azerbaijan National Academy of Sciences, Baku, AZ1 143, Azerbaijan
}

\begin{abstract}
The lower central plain of Thailand is characterized by a flat, low-lying area in the central region bound by mountain to the west, north and east and connected to a coastal shoreline of the Gulf of Thailand to the south as a sedimentary basin containing a thick sequence of Quaternary sediments. The present study focused on the Bangkok Clay, a dark grey to black, soft marine clay sandwiched between thin layers of peat and fluvial sediments. The Bangkok Clay is about 25 meters thick in the middle portion of the shoreline, tapering towards the basin margin to the west, north and east forming a half lens-shaped, dark grey clay body. The Bangkok Clay contains abundant and diverse organic remains including vertebrates, invertebrates, plants and microscopic algae. Palynological analysis has yielded diverse assemblages of pollen, spores and diatoms. The pollen and spores include several types of Avicenniaceae, Brownlowia sp., Combretaceae, Cyperaceae, Myrtaceae, Pinaceae, Poaceae, Rhizophoraceae, Sonneratiaceae, Xylocarpus sp., Acrostichum spp., Gleicheniaceae and Stenochlaena palustris. In addition, coastal diatoms derived from the palynological slides include Diploneis elliptica, Tryblionella cocconeiformis, Coscinodiscus radiata, Nitzchia sp., Tryblionella cf. compressa, Coscinodiscus sp., Paralia sulcata, Actinocyclus sp., Triceratium reticulum, Surirella sp., Cocconeis costata, and Thalassiosira sp. The Bangkok Clay was, therefore, formed in intertidal and shallow subtidal environments under a tropical moist climate. The Bangkok Clay is sandwiched between two thin peat layers. The basal peat developed through continuous accumulation of plant debris along the shoreline during the marine transgression of the Late Pleistocene to Early Holocene (ca. 8,000-7,000 years ago) whereas the upper peat formed during the Early Holocene to present day marine regression. Migration back and forth of the mangrove vegetation is recorded in these sediments as sea-level changed. A reddish-brown, mottled, stiff clay beneath the basal peat is devoid of pollen whereas the dark grey, silty clay layers overlying the upper peat, developed by a fluvial system migrating as the marine regression receded, contains palynomorphs from terrestrial environments including freshwater swamps. The pollen and spores include Ceratopteris thalictroides, Cocos sp., Cyperaceae, Ipomoea sp., Jussiaea sp., Lagerstroemia spp., Poaceae, Polygonum sp., Typhaangustifolia, Nymphaea sp., and Lygodium sp. Even though the lower central plain area developed after ca. 8,000-7,000 years ago, no evidence of human settlements has been observed until around 2,000 years ago. There are many ancient Dvaravati towns along the 8,000-7,000 year-old shoreline and further inland, except around the 8,000-7,000 year-old and younger paleo-gulf. Around 2,000 years ago when the Dvaravati people had settled their communities along the 8,000-7,000 year-old shoreline and inland, the marine regression moved to more or less the present position leaving swampy areas with dense sedge-dominant vegetation where no evidence of human settlements have been found. Our research suggests that pollen, spores and diatoms are important tools differentiating fluvial and marine sediments allowing us to trace the history of sea-level changes closely related to human settlements. However, detailed age determinations for the two peat layers are strongly recommended for tracing the spatial and temporal development of the shoreline to understand the lower central plain development and history of human settlements.
\end{abstract}

Key words: Bangkok clay, Ayutthaya paleo-gulf, Dvaravati, central Thailand. 


\section{Introduction}

The lower central plain [1] is a wide flat low lying terrain covering an area about 10,400 square kilometers (Fig. 1). The broadest portion is from Nakhon Pathom in the west to Chachoengsao about 180 kilometers to the east. From north to south the plain has a gentle slope with less than 4 meters per 100 kilometers [2]. The surface elevation above mean sea-level in Chainat is about 15 meters, gradually descending to 2.5 meters in Phra Nakhon Si Ayutthaya, and 1.5 meters in Bangkok on the Gulf of Thailand, a total distance of about 200 kilometers. The region is surrounded by mountain ranges in the west and east with some isolated hills in the north and the Gulf of Thailand in the south forming a sedimentary basin inclining southwards.

The area has four main rivers. The most important river is the Chao Phraya River which receives water from the Ping and Nan rivers in Nakhon Sawan and flows south past Phra Nakhon Si Ayutthaya, Bangkok and drains out into the Gulf of Thailand in Samut Prakan. The Mae Klong River collects water from the west, Khwae Yai and Khwae Noi rivers, in Kanchanaburi and flows through Ratchaburi draining into the Gulf of Thailand in Samut Songkhram. The Tha Chin River, between the Mae Klong and Chao Phraya rivers, flows from the Chao Phraya River in Uthai Thani, via Chainat, Suphan Buri, Nakhon Pathom and drains out into the Gulf of Thailand in Samut Sakhon. The Bang Pakong River is in the east originating from the Nakhon Nayok and Prachin Buri Rivers in Prachinburi and flows south via Chachoengsao and draining out into the Gulf of Thailand in Chachoengsao (Fig. 1). The four main rivers and their tributaries have for thousands of years provided vast volume of overbank sediments to the flood plain area during wet seasons.

The lower central plain area developed many

Corresponding author: Wickanet Songtham, Ph.D., research fields: geology, palynology. E-mail: wickanet@gmail.com. thousands of years ago. It used to be under seawater and was gradually exposed forming a piece of land, the lower central plain, where humans later settled their communities. However, the appearance of the plain and the history of human settlements can now be resolved using palynology.

\section{Previous Works}

The lower central plain is also regarded as a sedimentary basin, namely the "Lower Chao Phraya basin”. It is considered part of the Sunda shelf, a piece of submerged land connected to the Southeast Asian mainland. This wide continental shelf covers part of the Sunda archipelago of Borneo, Java and Sumatra as well as the shallow continental shelf of the South China Sea, Cambodian coastlines, Thai-Malay peninsula, Singapore, Borneo, Indonesian coastlines, Thailand and Vietnam. It is composed of thick sediments with a low angle slope [3]. It was exposed above sea-level during the last glacial maximum when the sea was about 116 meters below modern sea-level [4-6]. This exposed continental shelf covered a wide area, Sunda land, connected with the Asian mainland to Borneo, Java, and Sumatra [7].

The last glacial maximum ceased at around 21,000 years B.P. when sea-level had gradually risen from 116 meters below modern sea-level at a rate of about 0.1 meter/100 years. It stood at 114 meters below present sea-level at 19,000 years B.P. This sea-level rise continuously progressed at variable rates from 51 meters below present level at 10,000 years B.P. to be about 5 meters above present sea-level at 8,000-7,000 years B.P., the mid-Holocene highstand. After that, sea-level continuously declined to present day levels at about 1,000 years ago [7].

The lower central plain area at about 8,000-7,000 years B.P., mid-Holocene highstand, was a shallow sea known as Ayutthaya Paleo-gulf. After that the shoreline regressed south leaving a river delta plain as seen today [1, 8, 9]. Evolution of sedimentation in the Chao Phraya delta is classified into four stages [2] as 


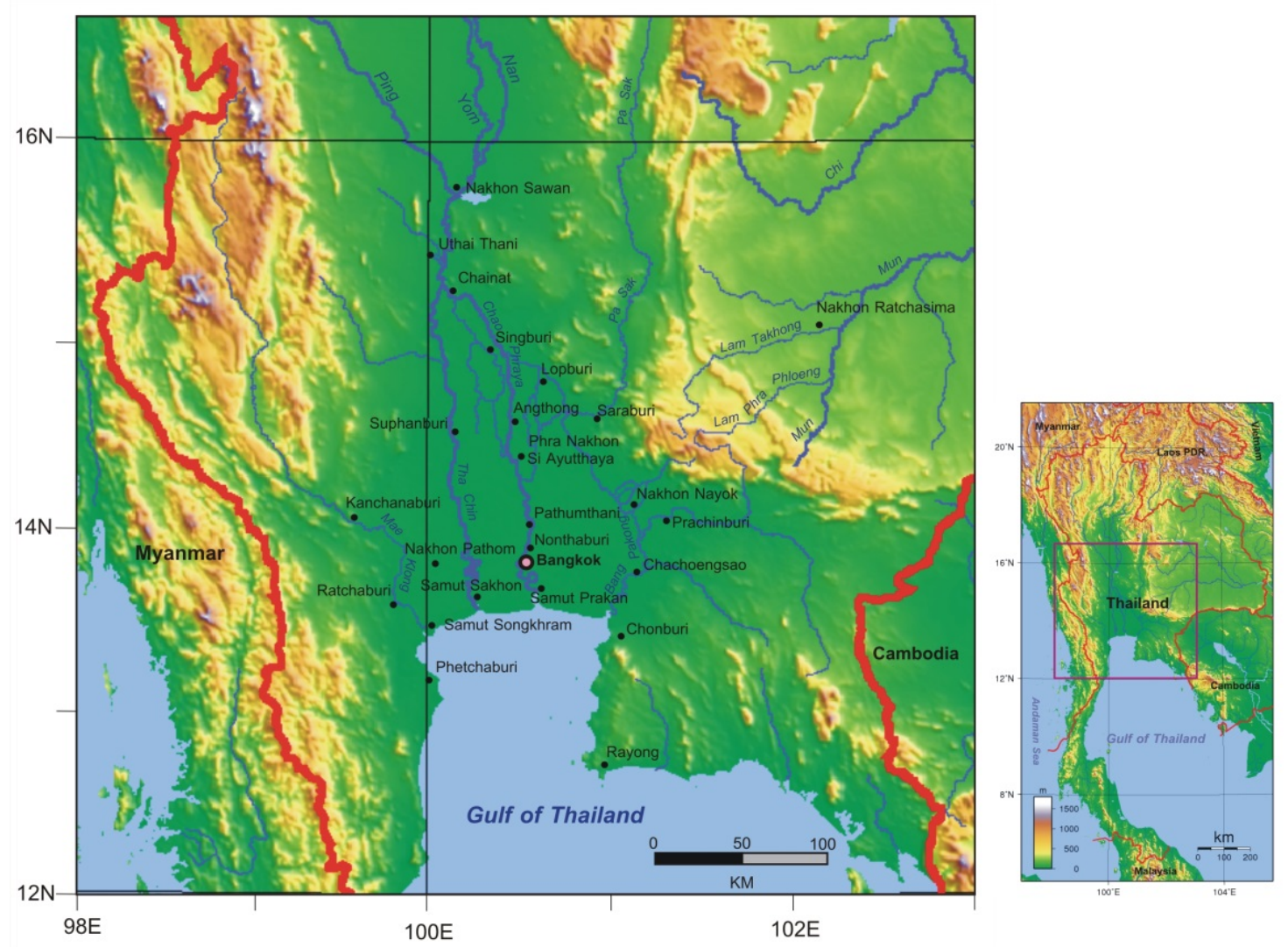

Fig. 1 Map showing topography, drainage system and city locations in the Lower Central Plain of Thailand.

\section{follows:}

Stage 1 (8,000-7,000 years B.P): At the time of the Mid-Holocene highstand, the coastline was located about 20 kilometers north of Phra Nakhon Si Ayutthaya where sea-level was standing at about 2-4 meters above present levels. A 30-kilometer long beach ridge was recognized about 30 kilometers SW of Phra Nakhon Si Ayutthaya. The sand of the ridge was derived from the Mae Klong fan delta.

Stage 2 (7,000-3,000 years B.P.): A large mud shoal was formed by sediments supplied by the delta of the Mae Klong and Chao Phraya rivers. This mud shoal extended eastward giving rise to the separation between the Ayutthaya paleo-gulf and the Gulf of Thailand.

Stage 3 (3,000-2,000 years B.P.): Rapid sedimentation took place about 2,000 years ago in the Ayutthaya paleo-gulf by shallow marine and fan delta sediments with dense mangrove vegetation. The sediment infilling was a result of progradation of fan delta sediments at the head of the paleo-gulf expanding southwards and continuing into stage 4 .

Stage 4 (2,000 years B.P. to present day): Rapid progradation of the fan delta along the coastline of Gulf of Thailand occurred at this time. Sediments from the rivers were directly transported to the coastline as river deltas filled in the paleo-gulf.

The lower central plain gradually developed by the time of the last marine regression from 8,000-7,000 years B.P., containing a long history of human settlements from prehistoric to historic periods. The first record of historic human activity in the area is Dvaravati (6th-13th centuries). After that, Lavo, Ayutthaya, and Thonburi communities successively occupied the area between the 7th and 18th centuries. Rattanakosin, the last empire, took over the area in the 18th century. The Dvaravati, the oldest historic occupants of the lower central plain, left evidence of 
ruined ancient towns and other archeological artifacts in close relation to ancient sea shores [10].

At present, Quaternary sediment in the Lower Chao Phraya basin is over 2,000 meters thick and is classified into two main groups [1]. The lower group comprises gravel, sand and clay with a thickness over 2,000 meters. The uppermost part of the group is stiff clay, grey to pale brown, with orange mottles and iron and manganese nodules. The lower group is Pleistocene in age. The overlying group is soft marine clay, dark grey to black, with sand and silt intercalations. This group contains abundant plant debris and marine animal remains. It is known as "Bangkok Clay" and is about 25 meters thick at the most, tapering towards the basin margin.

\section{Materials and Methods}

The five study areas for sediment samplings were soil pits used for commercial construction materials. The pits are large and deep enough to observe sedimentary profiles on the pit walls. Samplings were taken along the pit walls in vertical soil profiles at intervals of 20 centimeters. The soil pits used are in the areas of Suphanburi, Nakhon Pathom, Nakhon Nayok, Chachoengsao, and Chonburi.

Pollen processing and analysis was undertaken at the Micropaleontology Laboratory of Nakhon Ratchasima Rajabhat University. The techniques used involved chemical treatment, centrifugal separation and filtration. Ten grams of sediment were treated by $10 \%$ $\mathrm{HCl}$ to extracting carbonate minerals and $49 \% \mathrm{HF}$ to extract silicate minerals. Humic material was dissolved by $5 \% \mathrm{KOH}$ and subsequently standard acetolysis was applied. The final procedure was microscopic slide preparation using Eukitt as a mounting medium for identification under the light microscope.

\section{Results}

Both field and laboratory activities are used to describe the five areas. Geological settings and palynological associations obtained from the five areas revealed continuous lateral and vertical relationships. Palynological treatment yielded enough palynomorphs and diatoms in some places (Figs. 2-4) to enable the phytogeography, climate, and depositional environments to be described. The results from the different soil pits are as follows.

\subsection{Uthong-Ban Bang Kung Soil Pits}

This study area consists of two soil pits and one drill hole. The soil pits include Bung Lad Nam Tian Floodway Project, Ban Don Kum, Tambon Krachan, Uthong district, Suphanburi (14²3’31.52” N/99 55’55.76” E) and Ban Bang Kung soil pit in Ban Bang Kung, Tambon Bang Kung, Mueang Suphanburi (14²7’33.58” N/100¹'24.72” E). The drill hole was in the area of Wat Muang (hole \# DH27), Tambon Jedee, Tambon Uthong, Suphanburi (14²2'17" N/9957’52.12” E). Bang Kung soil pit was a large and deep pit clearly displaying the sedimentary succession. The lower layer of sediment is a yellowish-brown stiff clay, but color grey, dark grey, brown and yellowish red in some places. It is highly oxidized with, rare palynomorphs. The grey sediment yielded Ceratopteris thalictroides, Jussiaea sp., Typhaangustifolia, Cyperaceae, and Cocos sp. The sediment also yielded common freshwater mollusk shells in the upper portion. The pollen, spores and mollusk shells represent a freshwater depositional environment.

Sediment in the Bung Lad Nam Tian Floodway Project area is grey with abundant plant stems and roots. Freshwater mollusk shells are common to abundant in the sediment and include Pila sp., Filopaludina sp., Pseudodon sp., and Scabies sp. Palynomorphs comprise Ceratopteris thalictroides, Nymphaeae sp., Cyperaceae, Jussiaea sp., Ludwigia sp., Ipomoea sp., Polygonum sp., and Lagerstroemia spp. The sediment in this area was deposited in a freshwater swamp environment closely related to the Ban Bang Kung soil pit.

Sediment from the drill hole in Wat Muang was derived from a 3.6 meters deep hole but samples used 
Evidence from Pollen, Spores and Diatoms

for palynological treatment were derived from 2.8 to 3.6 meters. Sediment between 3.6 and 3.2 meters contained common to abundant Lygodium sp. with sporadic Sonneratia spp. Sediment between 3.2 and 2.8 meters yielded common to abundant Sonneratia spp. and Acrostichum spp. It is interpreted that the sediment between 3.6 and 2.8 meters accumulated during a
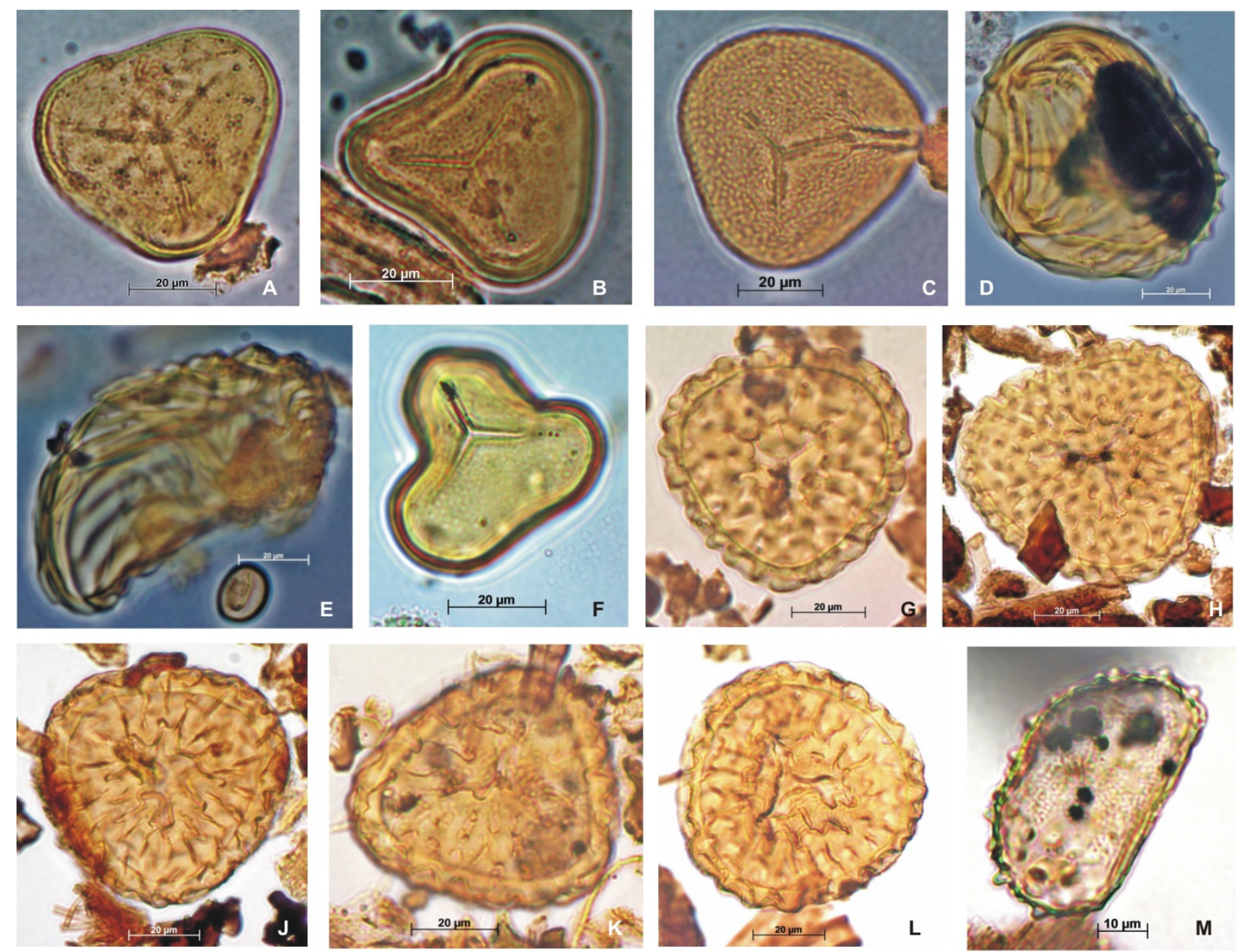
Tambon Don Phuedsa, Don Tum district, Nakhon
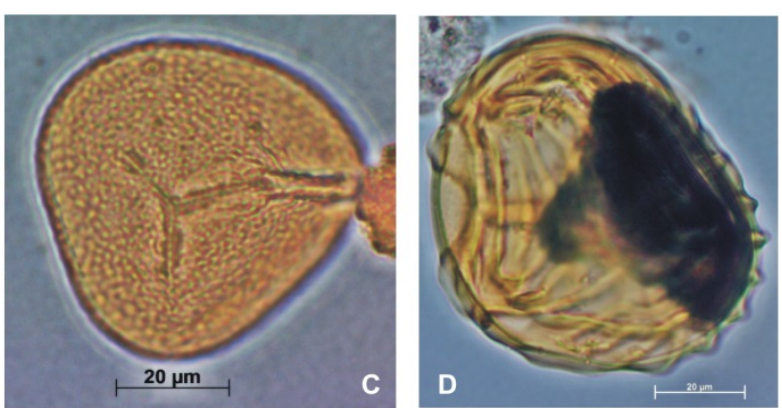

pits and the drill hole is regarded as fluctuating coastline during the mid-Holocene highstand.

\subsection{Don Tum Soil Pit}

The study area is in the south of Ban Hua Thanon,
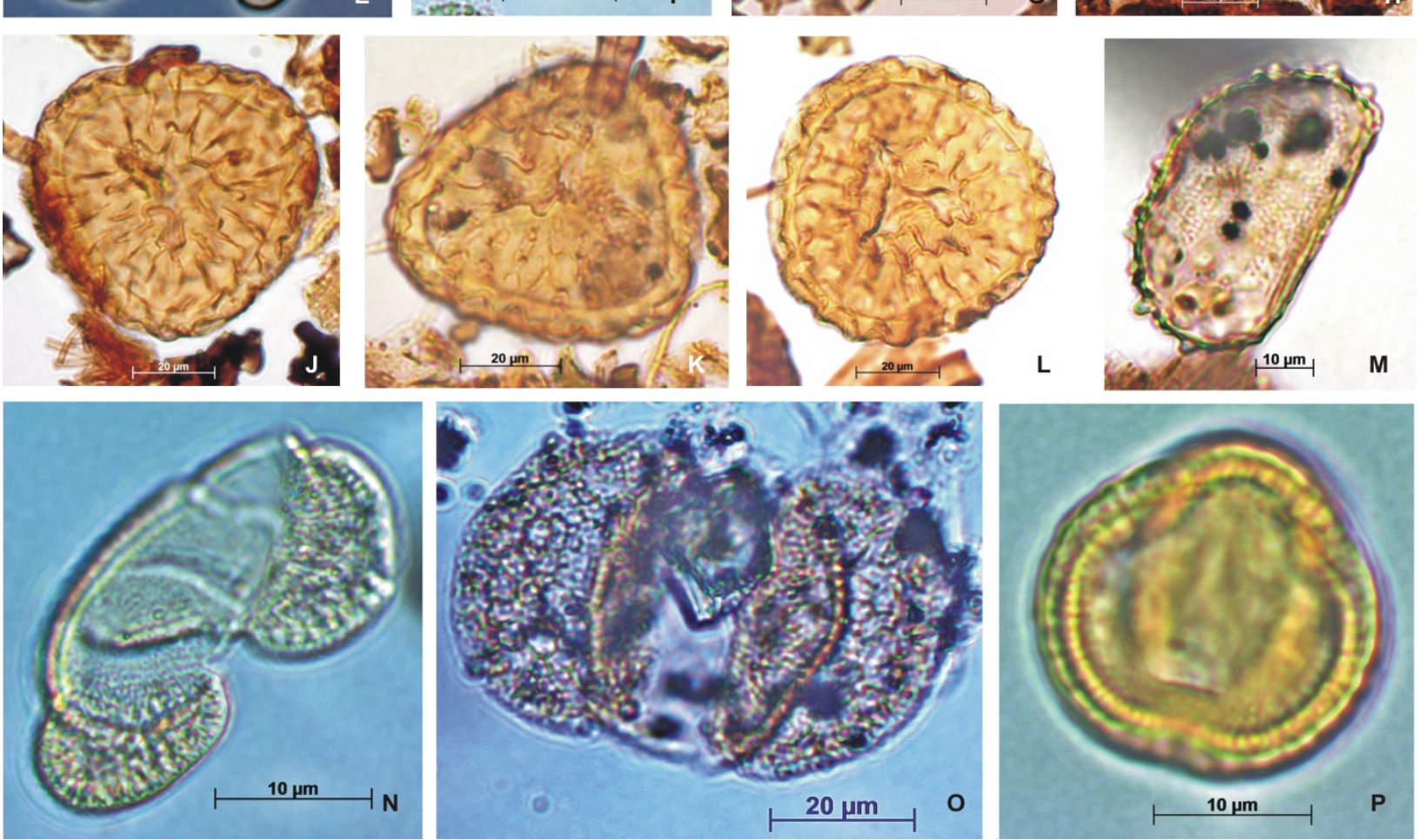

Fig. 2 Palynomorphs from sediment of Lower Chao Phraya basin; A-C: Acrostichum spp.; D-E: Ceratopteris thalictroides; F: Gleicheniaceae; G-L: Lygodium sp.; M: Stenochlaenapalustris; N-O: Pinus sp.; P: Avicennia sp. 
Development of the Lower Central Plain of Thailand with History of Human Settlements: Evidence from Pollen, Spores and Diatoms
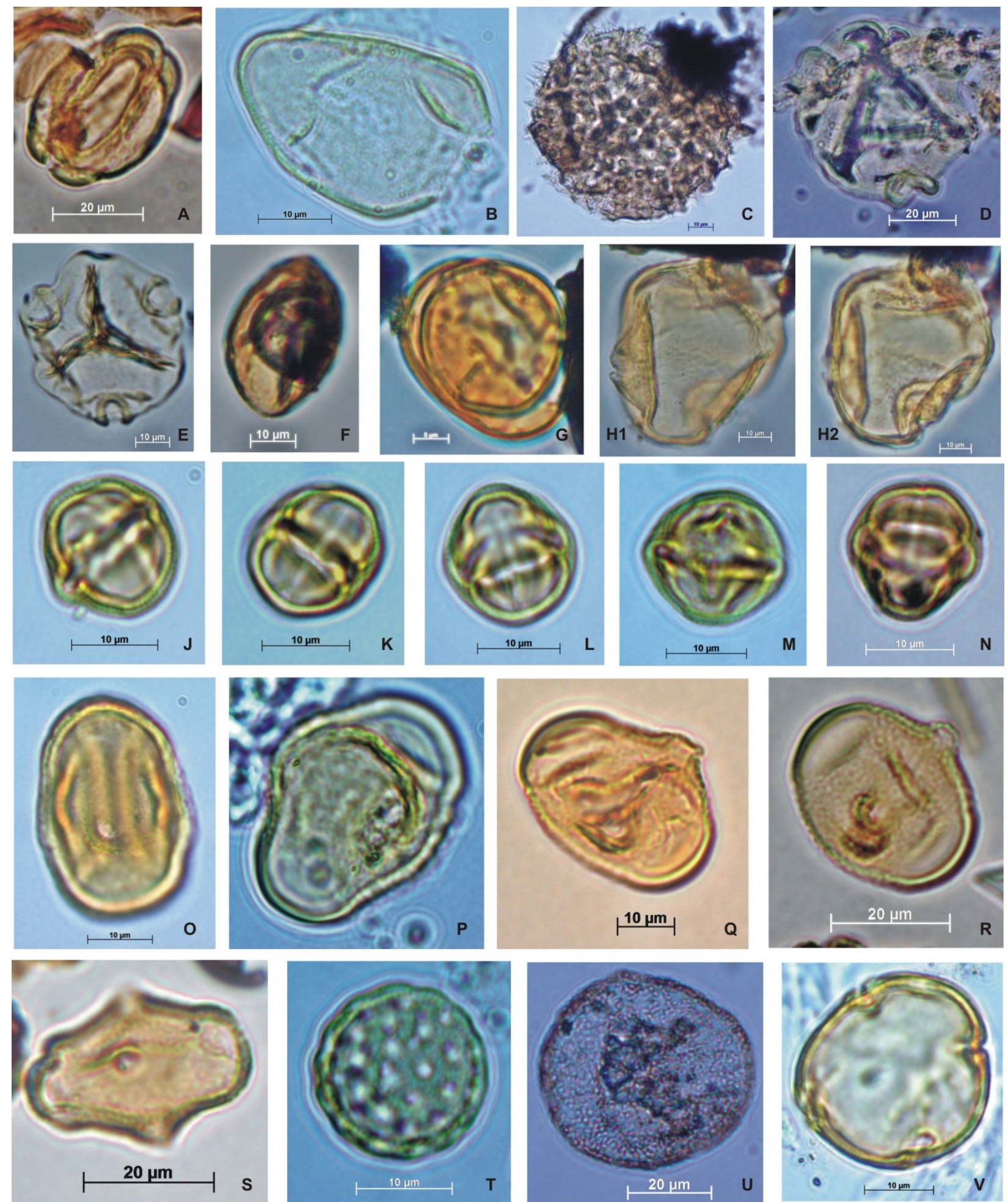

Fig. 3 Palynomorphs from sediment of Lower Chao Phraya basin; A: Barringtonia sp.; B: Cyperaceae; C: Ipomoea sp.; D-E: Jussiaea sp.; F-G: Lagerstroemia spp.; H: Ludwigia sp.; J-N: Rhizophoraceae; O-S: Sonneratia spp.; T: Suaedamaritima; U: Typhaangustifolia; V: Xylocarpus sp. 
Evidence from Pollen, Spores and Diatoms
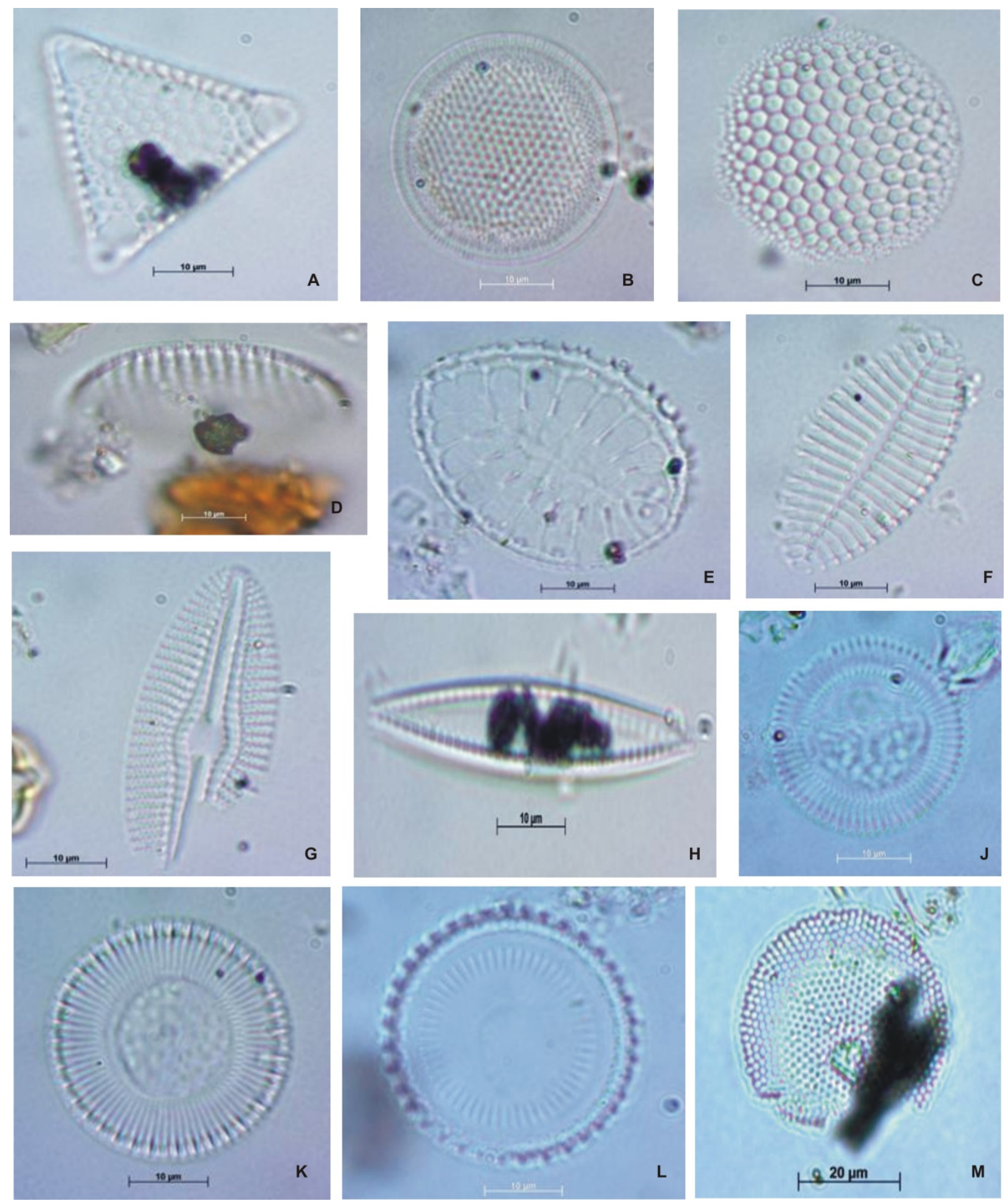

Fig. 4 Diatoms from sediment of Lower Chao Phraya basin; A: Triceratium reticulum; B: Coscinodiscus radiatus; C: Coscinodiscus sp.; D: Nitzschia cf. compressa; E: Surirella sp.; F: Cocconeis costata; G: Diploneis elliptica; H: Nitzschia sp.; J: Cyclotella striata; K: Paralia sulcata; L: Melosira sulcata; M: Actinocyclus sp.

Pathom (1355’03” N/10007’11” E). It was a large and deep soil pit with black clay clearly exposed, sandwiched by peat layers. The black clay yielded mostly Rhizophoraceae, Sonneratia spp., and Acrostichum spp. This clay accumulated along a coastline near a mangrove forest. 


\subsection{Khlong Sib Si Soil Pit}

This large 27 meters deep soil pit is on the east of Khlong Sib Si (an irrigation canal) in Tambon Bung Sarn, Ongkharak district, Nakhon Nayok (1400’40”, N/10055'30” E). Sedimentary layers were clearly visible with yellowish-orange stiff clay in the lower part, overlain by a dark grey soft clay layer. A thin peat layer was at the lowermost part of the grey soft clay with pieces of carbonized wood in some places. $\mathrm{C}^{14}$ dating of the woods is between 7,050-7,620 years B.P. There was a thin mollusk shell layer about three meters above the basal peat layer. Some places were dominated by mollusk shells, Pholadidae, with elongated valves orientated with their long axes more or less in upright positions. The mollusk valves always aligned their anterior sides downwards and posterior sides upwards. The orientation of the Pholadidae valves is strong evidence that the mollusk shells are in situ deposits representing the original positions of the living mollusks in their burrows. A piece of mollusk shell was dated by $\mathrm{C}^{14}$ as 5,050 years B.P. [11].

The yellowish-orange clay lacked palynomorphs whereas the overlying dark grey clay yielded significant pollen assemblages containing Stenochaena palustris, Ceratopteris thalictroides, Acrostichum spp., Avicennia sp., Suaedamaritima, Xylocarpus sp., Rhizophoraceae, and Sonneratia spp. [12]. Evidence from peat, mollusk shells, and palynology strongly confirms that the dark grey clay layer accumulated in a marginal marine environment close to mangrove forests.

\subsection{Bang Nam Priao Soil Pit}

This soil pit is in Bang Nam Priao district, Chachoengsao, close to the eastern railway (1351'42.63” N/10106'27.34” E). It is a small pit with a small pond. Dark clay on the pit wall contained sporadic occurrences of Pholadidae shells. Palynomorphs from the clay were dominated by sporadic occurrences of Rhizophoraceae and Avicennia sp. with somewhat low biodiversity. Diatoms are abundant with high biodiversity including Triceratium reticulum, Coscinodiscus sp., Nitzschia sp., Surirella sp., Tryblionella cocconeiformis, Diploneis elliptica and Paralia sulcata. Most diatoms are coastal species suggesting that sedimentation took place off the coast but still within the dispersal range of mangrove pollen.

\subsection{Tha Kham Soil Pit}

This study area was a large soil pit excavated for water storage supplying water to the local community. It is in Ban Tha Kham, Tambon Tha Kham, Phanat Nikhom district, Chonburi (13³3'20.63” N/101¹1’22.58” E). A dark clay from the pit wall yielded Rhizophoraceae, Sonneratia spp., Suaedamaritima, Stenochaena palustris, Cyperaceae, Acrostichum spp., and Xylocarpus sp. together with a species of freshwater microscopic alga, Botryococcus braunii. This palynological assemblage suggests that

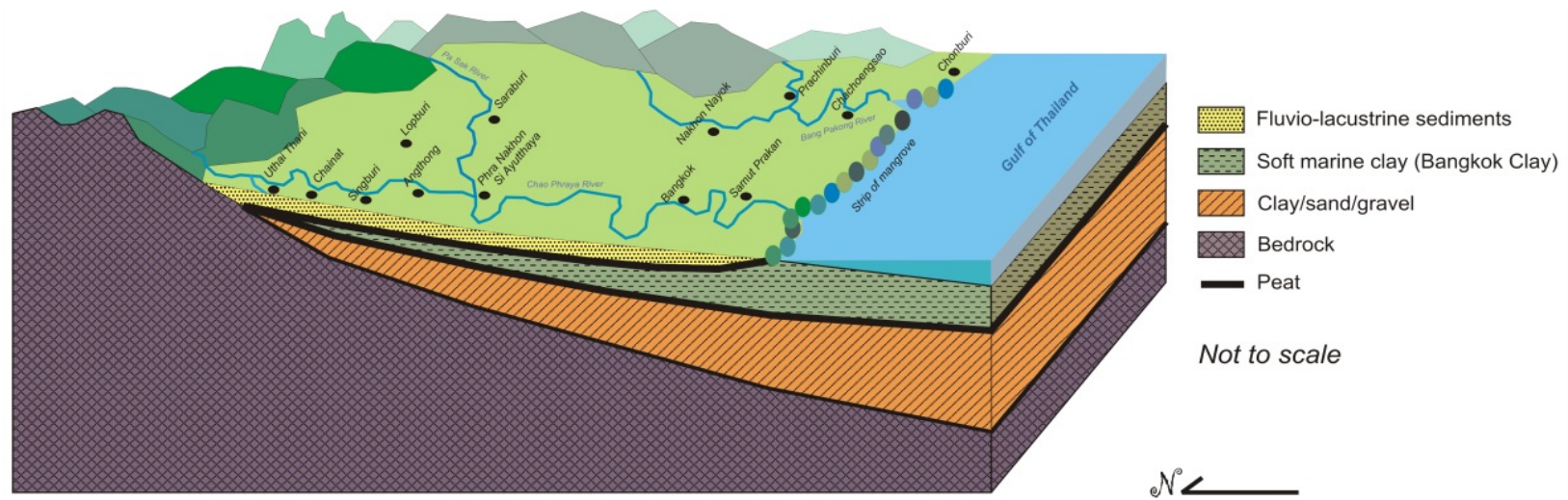

Fig. 5 Block model of Lower Chao Phraya basin showing eastern part of lower central plain and cross section of sedimentary succession. 


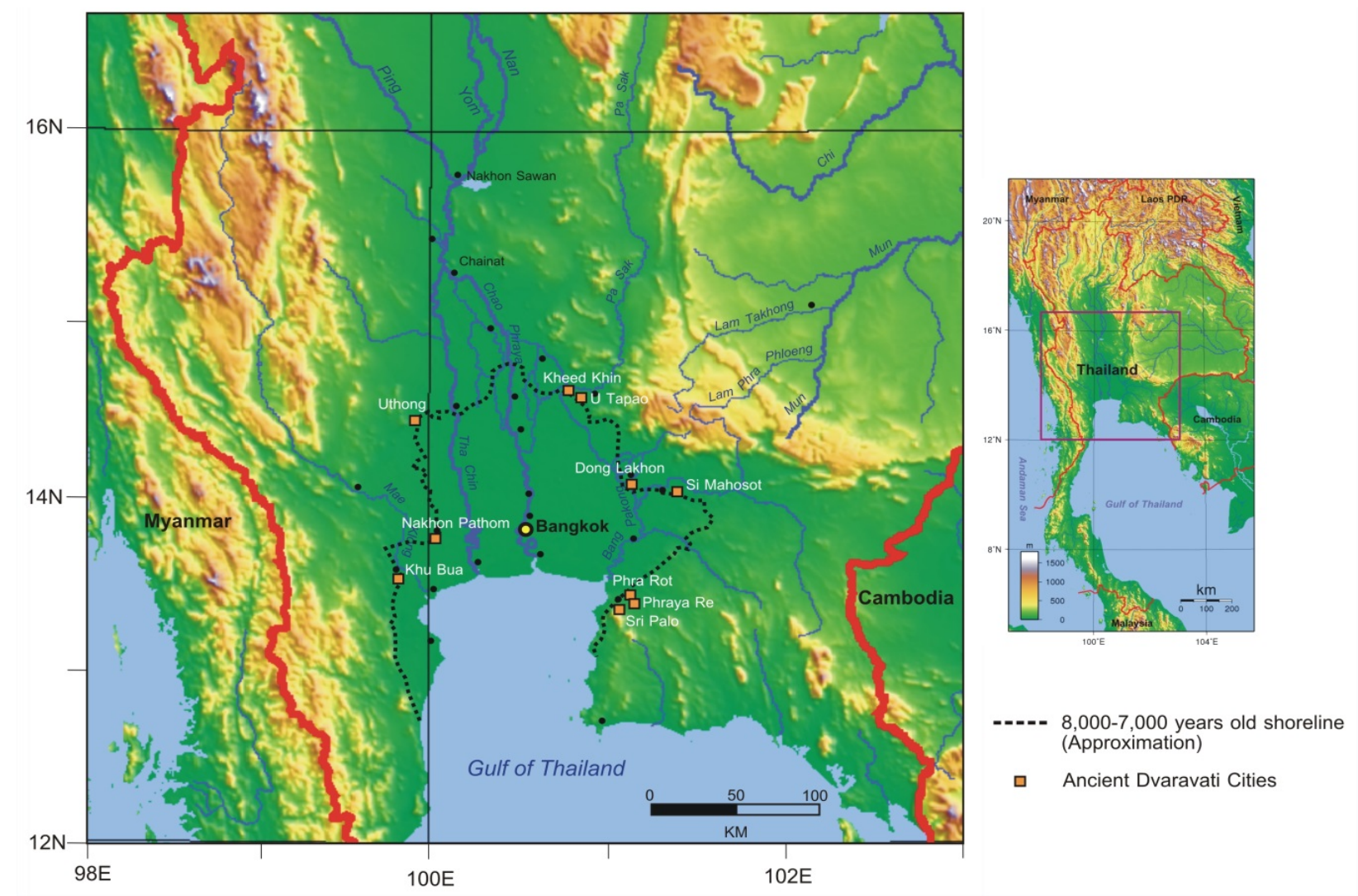

Fig. 6 Map of the lower central plain of Thailand showing mid-Holocene highstand (ca. 8,000-7,000 years old) and locations of Dvaravati cities.

sedimentation took place in a marginal marine environment dominated by mangrove with influxes of freshwater alga. The possible site of sedimentation was around an estuarine river environment close to sea.

\section{Conclusions}

The Lower Chao Phraya basin is a sedimentary basin with successive sedimentary layers clearly visible. The dark grey to black soft marine Bangkok Clay, overlain by a fluvial sedimentary layer (Fig. 5), is most apparent.

The Bangkok Clay formed during the Latest Pleistocene marine transgression and Holocene marine regression. After the last glacial maximum, sea-level gradually rose to the mid-Holocene highstand, 8,000-7,000 years B.P., where sea-level stood at 4-5 meters above present sea-level. The lower central plain during this period was flooded by seawater transgressing inland with the shoreline passing Ratchaburi, Nakhon Pathom, Suphanburi, Ang Thong,
Saraburi, Nakhon Nayok, Prachinburi, Chachoengsao, and Chonburi. This shoreline was more or less along the modern basin margin. As the marine transgression proceeded the positions of the coastal strips of mangrove forest migrated leaving organic remains which later developed into a thin layer of basal peat. This basal peat overlying the pale brown stiff clay and is overlain by dark grey soft marine clay (Bangkok clay).

Sea-level at the maximum level, 4-5 meters above present sea-level, was at about 8,000-7,000 years B.P. After that sea-level gradually regressed causing changes in the position of shorelines as measured by the positions of mangrove forests. The gradual marine regression also generated another thin peat layer on the Bangkok clay together with fluvial sediment as the topmost layer of the lower central plain (Fig. 5).

From 8,000-7,000 years B.P. to around 2,000 years B.P., the marine regression gradually declined from the highstand to its nearby present position leaving a large 
piece of land, the lower central plain. However, the lower central plain area at about 2,000 years B.P. was dominated by swamps and wetlands with a dense vegetation of sedges and other monocotyledonous plants. The Dvaravati people at this time never settled in this area for these geographical and environmental reasons. They settled and built their towns in areas inland of the former 8,000-7,000 years old shoreline. That is why the ancient Dvaravati towns, around 2,000 years old, are found today located close to the 8,000-7,000 years old shoreline and why Vanasin and Supajanya (1981) claimed these Dvaravati towns were seaside towns. These towns today include Khu Bua (Ratchaburi), Nakhon Pathom, Uthong (Suphanburi), Kheed Khin and U-Tapao (Saraburi), Dong Lakhon (Nakhon Nayok), Sri Mahosot (Prachinburi), Phra Rot, Phraya Re, and Sri Palo (Chonburi) (Fig. 6). These Dvaravati towns were situated near the 8,000-7,000 years old shoreline while the actual shoreline at the time was very close to the present day sea-level position, in the vicinity of the southern part of Bangkok to the Phra PraDaeng in Samut Prakan. The shoreline during the Dvaravati period could not have extended northward beyond Bangkok and could not have reached to the key cities of the Dvaravati period [13].

\section{Acknowledgment}

This palynological research is a part of "Fossils from Sediment of the Lower Chao Phraya Basin Project" of the Department of Mineral Resources who gave financial support. Additional work was supported by the Northeastern Research Institute of Petrified Wood and Mineral Resources, Nakhon Ratchasima Rajabhat University. The authors are grateful.

\section{References}

[1] Sinsakul, S. 2000. "Late Quaternary Geology of the Lower Central Plain, Thailand.” Journal of Asian Earth Sciences 18 (August): 415-26.

[2] Tanabe, S., Saito, Y., Sato, Y., Suzuki, Y., Sinsakul, S.,
Tiyapairach, S., and Chaimanee, N. 2003. "Stratigraphy and Holocene Evolution of the Mud-Dominated Chao Phraya Delta, Thailand.” Quaternary Science Reviews 22 (April): 789-807.

[3] Hanebuth, T. J. J., and Stattegger, K. 2004. “Depositional Sequences on a Late Pleistocene-Holocene Tropical Siliclastic Shelf (Sunda Shelf, Southeast Asia).” Journal of Asian Earth Sciences 23 (March): 113-26.

[4] Geyh, M. A., Kudrass, H. R., and Streif, H. 1979. "Sea Level Changes during the Late Pleistocene and Holocene in the Strait of Malacca.” Nature 278 (March): 441-3.

[5] Hanebuth, T. J. J., Stattegger, K., and Grootes, P. M. 2000. "Rapid Flooding of the Sunda Shelf: A Late Glacial Sea Level Record.” Science 288 (5468): 1033-5.

[6] Hesp, P. A., Hung, C. C., Hilton, M., Ming, C. L., and Turner, I. M. 1998. "A First Tentative Holocene Sea-Level Curve for Singapore.” Journal of Coastal Research 14 (1): 308-14.

[7] Sathiamurthy, E., and Voris, H. K. 2006. Maps of Holocene Sea Level Transgression and Submerged Lakes on the Sunda Shelf. The National History Journal of Chulalongkorn University supplement 2: 1-44.

[8] Rau, J. L., and Nutalaya, P. 1983. "Geology of the Bangkok Clay.” Geological Society of Malaysia Bulletin 16 (December): 99-116.

[9] Woodroffe, C. D. 2000. "Deltaic and Estuarine Environments And Their Late Quaternary Dynamics on the Sunda and Sahul Shelves.” Journal of Asian Earth Sciences 18 (August): 393-413.

[10] Vanasin, P., and Supajanya, T. 1981. Ancient Cities on the Former Coastline of Central Thailand. Bangkok: Chulalongkorn University.

[11] Songtham, W., Phanwong, P., and Seelanan, T. 2007. "Middle Holocene Peat and Mollusk Shell from Ongkharak Area, Nakhon Nayok, Central Thailand: Evidence of in Situ Deposits during a Marine Transgression Period." In Proceedings of the International Conference on Geology of Thailand: Towards Sustainable Development and Sufficiency Economy (Geothai'07), 177-9.

[12] Punwong, P. 2007. "Pollen Deposit in Bangkok Clay from Ong Kharak District, Nakhon Nayok Province, and Their Implication on Paleophytogeography." M.Sc. thesis, Chulalongkorn University.

[13] Hutangkura, T. 2014. "A New Interpretation of the Boundary of Dvaravati Shoreline on the Lower Central Plain.” Damrong, Journal of the Faculty of Archaeology 13 (1): 12-44. 